\title{
A QUESTÃO DEMOCRÁTICA EM TEMPOS DE INCERTEZAS
}

THE DEMOCRATIC ISSUE IN TIMES OF UNCERTANTY

Rosangela Patriota Ramos ${ }^{1}$

Recebido em: 30 de setembro de 2020. Aprovado em: 17 de dezembro de 2020 .

RESUMO: Este artigo tem como proposta discutir o tema da democracia a partir da conjuntura política atual em contraponto a experiências históricas recentes, especialmente por intermédio da peça teatral Praça dos Heróis de Thomas Bernhard.

Palavras-chave: Democracia; Antissemitismo; Praça Dos Heróis; Thomas Bernhard

\begin{abstract}
This article aims to discuss the theme of democracy from the current political situation as a counterpoint to recent historical experiences, especially through Thomas Bernhard's Heroes' Square (HENDELPLATZ).
\end{abstract}

Keywords: Democracy; Anti-Semitism; Hendelplatz; Thomas Bernhard

1 Bolsista Produtividade CNPq. Professora Assistente Doutora do Programa de Pós-Graduação em Educação, Artes e História da Cultura da Universidade Presbiteriana Mackenzie. Professora Titular aposentada da Universidade Federal de Uberlândia. Autora de Antonio Fagundes no palco da história: um ator; A crítica de um teatro crítico; Teatro brasileiro: ideias de uma história (em coautoria com J. Guinsburg), Vianinha - um dramaturgo no coração de seu tempo e História e Teatro: discussões para o tempo presente, entre outras publicações. É uma das editoras do periódico Fênix - revista de História e Estudos Culturais. E-mail: patriota.ramos@gmail. com 
Existem décadas intermináveis, em que a história parece se arrastar. Eleições são vencidas e perdidas, leis são adotadas e revogadas, estrelas nascem e pessoas ilustres vão para o túmulo. Mas a despeito do caráter prosaico da passagem do tempo, as estrelas-guia da cultura, da sociedade e da política seguem as mesmas.

- Yascha Mounk, em O povo contra a democracia.

Acredito que, em maior ou menor proporção, o tema da democracia sempre esteve presente nos debates políticos, sociais e culturais. Eles marcaram o mundo ocidental desde meados do século XVIII.

Do reordenamento do Estado, a partir da instituição de três poderes independentes, a democracia representativa surgiu, primeiramente, com o estabelecimento do voto censitário e, em virtude de inúmeras lutas, o voto universal foi adotado por vários países. Com efeito, a democracia, a partir do século XIX, tornou-se o regime preferencial da maioria dos países da Europa Ocidental, da América do Norte e da América do Sul, fossem eles Repúblicas ou Monarquias Constitucionais.

No decorrer do século XX, porém, o impacto do nazifascismo sobre o Ocidente foi determinante para que o combate entre o Eixo e os Aliados se tornasse a grande contenda entre Democracia x Totalitarismo. Como reação a isso, após o fim da II Guerra, e, com ele, a exposição pública dos horrores dos campos de concentração e de toda uma gama de atrocidades possibilitaram a pactuação de estratégias políticas e diplomáticas, em torno dos Direitos Humanos e da Autodeterminação dos Povos. Aliás, esses princípios elementares são a base da criação da Organização das Nações Unidas, em 24/10/1945.

Em meio a esse processo, a União Soviética ampliou suas fronteiras, seja por apoio a governos estabelecidos, seja por invasão de territórios. Esse, sem dúvida, é um capítulo à parte, mas não será aqui debatido, porque o interesse, nesse introito, é recordar: uma nova polarização passou a nortear as relações internacionais. Em outros termos: o surgimento da Guerra Fria alimentou novos alinhamentos, especialmente, a divisão do mundo, do ponto de vista geopolítico, entre Ocidente e Oriente, ou, em termos político-econômicos, Capitalismo x Socialismo.

Em torno desse binômio, a partir da década de 1950, definiram-se acordos bilaterais/multilaterais, promoveu-se a criação de organizações de defesa como a Organização do Tratado do Atlântico Norte - OTAN -, em contraponto ao Pacto de Varsóvia, assim como se alimentaram pesquisas, debates político-ideológicos, rearranjos da ordem econômica, com expansão das multinacionais e as remessas de royalties dos países pobres para as matrizes desses empreendimentos. Por fim, mas não menos importante, o financiamento e apoio, por parte de Governos e de Agências de Inteligência, para a promoção de Golpes de Estados justamente em favor... da Democracia. 
Nesse sentido, para muitos de nós, especialmente para mim, que cresceram durante a ditadura militar (1964-1985), as perspectivas críticas, em relação à sociedade brasileira, começaram a ser despertadas pelas artes, em especial o teatro.

Porém, a razão dessa reminiscência reside no fato de que pelas palavras de inúmeros dramaturgos o tema da democracia começou a adquirir contornos e materialidade no meu cotidiano. Textos como Um grito parado no ar e Ponto de Partida (ambos de Gianfrancesco Guarnieri), Frei Caneca (Carlos Queiroz Telles), Corpo a Corpo e Longa Noite de Cristal (ambos de Oduvaldo Vianna Filho), Caminho de Volta (Consuelo de Castro), Calabar, o elogio da traição (Chico Buarque e Ruy Guerra), Gota d'Água (Paulo Pontes e Chico Buarque), ao lado de espetáculos como Mortos sem Sepultura (de Jean Paul Sartre, direção de Fernando Peixoto), Terror e miséria no Terceiro Reich (de Bertolt Brecht, direção de Fernando Peixoto), Investigação da Classe Dominante (de J.B. Priestley, direção de Flávio Rangel), entre tantos outros, foram meus mestres em minha educação artística e intelectual.

Digo isso porque oposição à ditadura militar significava, dentre outras coisas, lutar contra as prisões arbitrárias, contra a tortura e, principalmente, estar a favor da liberdade de expressão, do direito à opinião em consonância com uma sociedade menos injusta e mais igualitária.

Essa visão de democracia, acredito, atravessou inúmeros segmentos sociais e vários movimentos, com ressonância nacional e internacional, como a Luta pela Anistia e Diretas Já2. A reconquista do Estado de Direito e o restabelecimento de eleições para presidente, governadores e prefeitos, juntamente com o fim dos mandatos biônicos para senador, de certa forma, nos fez acreditar: a partir do ano de 1985, estaríamos a viver sob a égide de um Estado Democrático.

Nessa euforia, os brasileiros, no decorrer da década de 1980, vivenciaram eleições para governadores, prefeitos, e tiveram o grande ápice, em 1989, com as eleições presidenciais. Em vista de toda expectativa contida nesses processos eleitorais, a imprensa houve por bem em adjetivá-la como festa de democracia.

Restabelecida a normalidade democrática, dramaturgicamente, a cena teatral no Brasil buscou novos redimensionamentos, em torno de questões comportamentais, existenciais e das narrativas pós-dramáticas, ao lado do working in progress e do processo colaborativo.

Enfim, outras palavras, sentidos e significados passaram a ocupar nossos palcos. Em termos políticos, sociais e econômicos, as expectativas de pautas voltadas para economia e cultura globalizadas tornaram-se predominantes nos discursos governamentais, proferidos em diferentes instâncias, apesar da presença de setores para os quais as demandas sociais continuaram a ser prioridades.

Os anos se passaram e, de certa maneira, o mundo globalizado aparentava um dado equilíbrio. Afinal de contas, o grande fantasma do comunismo agora era um pobre espectro. Ele se fazia presente em algumas repúblicas latino-americanas e na paradigmática ilha de Fidel Castro, enquanto o Partido Comunista Chinês, por intermédio de práticas totalitárias, implementou com um grande êxito o capitalismo de Estado.

Como a reforçar essa nova ordem internacional, o mundo fundado entre expectativa e sonhos

2 Gostaria de ressaltar: estou apenas mencionando as manifestações de ordem geral, sem me ater às especificidades atinentes aos inúmeros movimentos que estavam em atividades no período. 
de projetos democráticos, no decorrer dos anos 1980, viu a ascensão de Margarete Thatcher ao cargo de Primeira-Ministra do Reino Unido e, com ela, a implementação das pautas neoliberais. Seu governo, juntamente com a atuação do republicano Ronald Reagan, à frente da Presidência dos Estados Unidos, teve grande impacto na economia mundial.

Assistimos também, muito consternados, à morte do papa João Paulo I e à ascensão de João Paulo II, o papa polonês. Sua Santidade, não apenas combateu práticas autoritárias em seu país como também se tornou uma voz expressiva na defesa de posturas mais conservadoras no seio da Igreja Católica, tendo sido responsável pelo sufocamento da Teologia da Libertação na América Latina, com a aposentadoria de cardeais combativos, a exemplo de D. Helder Câmara - arcebispo de Recife e Olinda -, pelo silenciamento de vozes como a do Frei Leonardo Boff, além da divisão da Arquidiocese de São Paulo, com vistas a enfraquecer a atuação institucional de D. Paulo Evaristo Arns - cardeal arcebispo de São Paulo.

Em meio a esses acontecimentos, presenciamos, em 1989, a Queda do Muro de Berlim e o início do processo de reunificação das duas Alemanhas. Já nos primeiros anos de 1990, o mundo acompanhou o debate em torno do polêmico livro do filósofo nipo-americano, Francis Fukuyama, $O$ fim da História e o último Homem.

Nesse ambiente, as relações internacionais passaram a ser identificadas por uma nova ordem mundial. Porém, esses reordenamentos trouxeram paz e prosperidade nos distintos continentes?

Claro que não!

Os embates do Oriente Médio tomaram proporções catastróficas, haja vista a Guerra do Iraque, as invasões no Afeganistão, os conflitos árabes-israelenses, as ações do Talibã, a destruição de vilas, cidades e países inteiros. A isso, devemos acrescentar os embates em território africano, nos seguintes países: Sudão e Sudão do Sul, Nigéria, Ruanda, Mali, Burundi, República Democrática do Congo e Angola. Tudo isso, sem esquecer, as guerras étnicas em virtude do fim da antiga Iugoslávia.

A crise humanitária assumiu dimensões dramáticas, com novas ondas imigratórias e com a fome assolando parte significativa do planeta Terra.

É evidente, não tenho condição alguma de discutir e sequer explanar sobre cada um desses processos de luta, mas considero importante esse registro, pois foram essas as bases históricas nas quais a democracia se desenvolveu, no decorrer do século XX e nas duas primeiras décadas do século XXI.

O mundo contemporâneo, mesmo imerso nessas contradições, promoveu em inúmeras sociedades, que estavam sob a normalidade democrática, importantes discussões em torno das diferenças, a saber: étnica, religiosa e de gênero. Essas demandas articuladas a atuações sistemáticas, em nível social e institucional, permitiram, mesmo timidamente, o movimento de algumas estruturas.

Em diferentes países, em ritmos próprios, surgiram, sem grandes alardes, bandeiras xenófobas, racistas e discriminatórias. Até então, considerados adormecidos pelas democracias contemporâneas, grupos identificados com essas plataformas, a princípio, invisíveis para os nossos olhos, se organizaram em associações, em grupos de whatsApp, no Facebook, no Twitter e no Instagram.

Embora esses deslocamentos estivessem ocorrendo na sociedade civil, para muitos, as vitórias políticas, ao redor do mundo, de segmentos conservadores foram recebidas com incredulidade e 
estupefação. Como compreender a eleição de Donald Trump, nos Estados Unidos, a liderança de Matteo Salvini juntamente com a presença, no parlamento, de legendas como Força Itália, Liga Norte e Nós com a Itália, ao lado do governo de Viktor Órban, na Hungria, do gabinete conservador na Áustria, da presença da extrema-direita alemã no Bundestag e de Marine Le Pen no Parlamento Europeu, além de ela ter chegado ao segundo turno das eleições presidenciais francesas, em 2017? Por fim, mas não menos importante, e a eleição de Jair Bolsonaro no Brasil?

A meu juízo, esses acontecimentos, para diversos setores, foram vistos isoladamente, isto é, os processos de luta foram desencadeados por embates localizados. No entanto, nessa rápida narrativa, busquei evidenciar como essas pontas soltas, na verdade, são desdobramentos de concepções de políticas, sociais, culturais. Elas, de forma ampla, tecem uma maneira de compreender o mundo e, com isso, acabaram construindo espaços de disputas e imposição, pela força, de países sobre outros.

Quando nos deparamos com as instigantes reflexões oriundas de livros como $O$ povo contra a democracia (de Yascha Mounk - São Paulo: Companhia das Letras, 2018), Crises da democracia (de Adam Przeworski - São Paulo: Companhia das Letras, 2019), Como as democracias morrem (Steven Levitsky e Daniel Ziblatt - Rio de Janeiro: Zahar, 2018) constatamos: as preocupações centrais se concentram nas dinâmicas estabelecidas pelo Estado de Direito e como estas podem ser ameaçadas por pautas econômicas, práticas culturais e tensões sociais. Porém, é preciso acrescentar: a democracia não se coloca em risco somente quando as regras institucionais são violadas. Pelo contrário, tais desrespeitos apenas tornam visíveis ações disseminadas no interior do tecido social. Salvo melhor juízo, os princípios democráticos estão em permanente condição de fragilidade quando se considera natural o exercício da discriminação, quando se avalia como lógica correta a vitória da eficiência e da maximização dos lucros em detrimento de decisões em prol do bem-estar da maioria da população, ou quando o livre pensamento se vê acossado frente a ideias defendidas por grandes conglomerados e corporações.

Dito de outra maneira: afirmações como as instituições estão funcionando são figuras de retórica. Tal procedimento é o mínimo que se espera de uma sociedade estruturada em torno da democracia representativa. Mas isso não é suficiente porque, em torno dessa premissa, transgressões foram aceitas e outras ignoradas, em favor da construção de grandes maiorias. Ao lado disso, a predominância de razões instrumentais, a transmutação do princípio da cidadania em direitos e deveres dos consumidores, a pouco e pouco, pavimentaram os caminhos e, nos dias de hoje, colocaram as sociedades em estado de alerta frente à defesa do binômio liberdade e justiça.

Como explicar tais descompassos?

Como já disse, a arte me faz enxergar o mundo com maior clareza e poesia, como também ela é chave para sua compreensão. Por isso, para externar possíveis respostas para a indagação acima, me apropriarei de uma das mais belas passagens do filme $O$ Poderoso Chefão - Coda - a morte de Michael Corleone (Francis Ford Copolla, 1990). Michael Corleone vai ao Vaticano para conversar com o Cardeal Lamberto sobre o não cumprimento do acordo assinado entre ele e a Immobiliare. Após ouvir atentamente o relato, Lamberto caminha em direção a uma fonte e dela retira uma pedra. Volta-se para Michael e diz: Veja esta pedra. Está na água há muito tempo, mas a água não pene- 
trou nela. Em um rápido movimento com as mãos, o cardeal quebra a pequena rocha e constata: Veja. Perfeitamente seca. A mesma coisa aconteceu com os homens na Europa. Durante séculos eles foram cercados pelo Cristianismo, mas Cristo não penetrou neles. Cristo não vive dentro deles.

Tais palavras, sem dúvida, evidenciam o fato de que o Cristianismo não se tornou um ethos. Longe disso, ele passou a existir como reprodução mecânica de ritos e práticas, sem se efetivar como uma vivência capaz de transformar valores e construir princípios de solidariedade e respeito.

Por esse ângulo, estabelecendo um paralelismo com a nossa discussão, não seria pertinente indagar se, para muitos de nós, a democracia não se tornou apenas uma palavra de efeito? As práticas democráticas efetivamente permearam o cotidiano das sociedades ou os instrumentos do Estado de Direito ficaram restritos apenas à configuração geral das instituições?

$\|$

A fim de dar materialidade às ideias aqui debatidas, me reportarei a um tema fundamental para a reconstrução das democracias após o fim da II Guerra Mundial: o Holocausto Judaico.

Apesar da complexidade do tema e de seus desdobramentos, me interessa, nessas circunstâncias, pensar as reações institucionais perante as atrocidades ocorridas nos campos de concentração nazistas contra os judeus ${ }^{3}$. Em termos geopolíticos, a principal resposta ocorreu, em 1948, quando em uma sessão da ONU foi aprovada a criação do Estado de Israel. Na sociedade civil, surgiram associações de sobreviventes, ao lado da criação de museus, memoriais, centros de documentação, em sintonia com a produção de filmes e documentários, dentre eles, estão A lista de Schindler (1993, de Steven Spielberg) e Shoah (1985, de Claude Lanzmann). Somando-se a essas iniciativas, vieram a público inúmeras obras memorialísticas, os escritos de Primo Levi são um exemplo, juntamente com vários estudos acadêmicos no campo das Humanidades.

A cada revelação, a perplexidade e a indignação, muitas vezes, se somavam ao silêncio diante do inefável. Como explicar o ocorrido? Por que se permitiu que tal estágio de desrespeito à vida humana se estabelecesse entre nós? O historiador François Furet, em seu livro O Passado de uma Ilusão, buscou na medida do possível dar alguma inteligibilidade aos acontecimentos rechaçados no decorrer da segunda metade do século XX:

Contudo, não existe antes do século XX governo ou regime ideológico. Talvez possamos dizer que Robespierre esboçou as suas características na primavera de 1794, com a festa do Ser Supremo e o Grande Terror. Mas aquilo só durou algumas semanas e a referência ao Ser Supremo é de tipo religioso, ao passo que entendo aqui por ideologias os sistemas de explicação do mundo através dos quais a ação política dos homens tem um caráter providencial, com exclusão de toda divindade. Neste sentido, Hitler, por um lado, e Lênin, por outro lado, fundaram regimes desconhecidos antes deles. Regimes cujas ideologias suscitaram não só o interesse, como também o entusiasmo de uma parte da Europa do pós-guerra; e não apenas nas massas populares, mas também nas classes cultas, apesar do caráter grosseiro das ideias ou dos raciocínios. Sob este aspecto, o nacional-socialismo é imbatível, um amálgama con-

3 Embora a comunidade judaica tenha sido a vítima preferencial da perseguição nazista, os campos de concentração, inicialmente, foram criados para segregar os adversários políticos do regime de Adolf Hitler como políticos comunistas e social-democratas. Posteriormente, foi a vez dos deficientes físicos, mentais e criminosos. negros, ciganos, testemunhas de Jeová. 
fuso de autodidata, enquanto o leninismo possui um pedigree filosófico. Contudo, mesmo o nacional-socialismo, para não falarmos do fascismo mussoliniano, conta entre os intelectuais debruçados sobre seu berço de monstro alguns dos grandes espíritos do século, começando por Heidegger. [...]. Para ter uma ideia do poder do fascismo e do comunismo sobre os intelectuais, aliás, um francês só precisa olhar para o seu próprio país, velha pátria europeia da literatura, onde a NRF do entreguerras ainda dá o tom: Drieu, Céline e Jouhandeau, por um lado, Gide, Aragon e Malraux, por outro. O espantoso não é o intelectual compartilhar o espírito do tempo. É ele ser presa deste, em vez de tentar dar a ele o seu toque. A maior parte dos grandes escritores franceses do século XIX, sobretudo na geração romântica, fez política, frequentemente como deputados, às vezes como ministros; mas foram autônomos e, aliás, inclassificáveis, por isso mesmo. Os do século XX se submetem às estratégias dos partidos e, de preferência, à política dos partidos extremos, hostis à democracia. Neles desempenham apenas um papel, acessório e provisório, de figurantes, manipulados como todos e sacrificados quando preciso à vontade do partido. Assim, não podemos escapar à questão do caráter ao mesmo tempo geral e misterioso dessa sedução ideológica. É mais fácil adivinhar por que um discurso de Hitler comoveu um alemão sobrevivente de Verdun, ou um burguês berlinense anticomunista, do que compreender a ressonância que ele teve em Heidegger ou em Céline (FURET, 1995, p. 16-17)

O desafio proposto por Furet, sem dúvida, nos obriga a olhar para nossas entranhas socioculturais, a fim de compreender tais ocorridos como mais que um hiato, em meio à normalidade institucional. Para isso, vejam, o cinema novamente me amparando, com advertência feita pela personagem Remy, em uma aula de História, no filme Declínio do Império Americano (1986, Denys Arcand): a história não é uma ciência moral. Noções como os direitos, a compaixão, a justiça são noções estranhas à História.

No entanto, os horrores da II Guerra Mundial trouxeram consigo julgamentos morais, pois era inadmissível estabelecer dúvidas ou explicações para o que fora qualificado como crimes contra a humanidade4.

Salvo considerações mais apropriadas, tais circunstâncias permitiram estabelecer a crença de que tais questões estivessem, de certa maneira, apaziguadas e, sob esse prisma, ao mundo contemporâneo caberia a tarefa de não mais permitir o reavivar dessas formas de pensamento e de ações político-culturais com esses teores.

Acreditávamos, apesar de todos os conflitos e mazelas já mencionadas, a democracia estava em segurança. Afinal, as instituições estavam funcionando.

Porém, na segunda metade do século XX, historiadores franceses, norte-americanos, ingleses, entre outros, se organizaram em torno de ideias classificadas como negacionismo do Holocausto. Elas visavam demonstrar a inexistência de uma política deliberada, por parte do Estado Nazista, para exterminar a comunidade judaica. Para isso, procuravam, a partir da pesquisa documental, demonstrar a impossibilidade de provar a existência das câmaras de gás 5 .

As tensões e o nível de acirramento envolveram, de um lado, os negacionistas e, de outro, os seus opositores, inclusive, com a abertura de processos judiciais. O pesquisador britânico David

4 Não é objeto desta reflexão, mas indícios importantes dessa discussão foram as duras críticas sofridas pela filósofa Hannah Arendt, principalmente, por parte da comunidade judaica, em decorrência de seu livro Eichmann em Jerusalém (São Paulo: Companhia das Letras, 1999), no qual, após acompanhar o julgamento do nazista Adolf Eichmann, elaborou o conceito banalidade do mal, considerado por ela a maior ameaça às sociedades democráticas.

5 Dentre os nomes mais expressivos dentre entre negacionistas estão os nomes de Abdel Aziz al-Rantissi, David Irving, Horst Mahler, Israel Shamir, Léon Degrelle, Otto Ernst Remer, Paul Rassinier, Richard Williamson, Robert Faurisson, Roger Garaudy, entre outros. 
Irving, considerado uma das grandes autoridades mundiais sobre Segunda Guerra e um polemista em prol do nazismo, interpelou, junto à Corte Inglesa, a editora Penguin e a historiadora norte-americana Deborah Lipstadt, pois, em sua avaliação, sua reputação profissional fora maculada. Lipstadt, em seu livro, Negando o Holocausto, o identificou como admirador de Hitler e falsificador de documentos. No entanto, ao final do julgamento, o juiz Charles Gray deu ganho de causa à Lipstadt e à Penguin'6.

Descrever os inúmeros embates entre negacionistas e seus opositores, inquestionavelmente, exigiriam outro percurso para essa reflexão. Todavia, é importante registrar: os resultados desses enfrentamentos, em absoluto, significaram apenas divergências interpretativas. Eles expuseram feridas não cicatrizadas e demonstraram a presença, entre nós, de temas e abordagens vistos, até aquele momento, como excluídos de nossas agendas políticas e culturais.

A perplexidade decorrente dessas discussões mobilizou expressivos intelectuais de nosso tempo como, por exemplo, o historiador Pierre Vidal-Naquet. Este, no esforço de compreender as implicações contidas nessas contendas, escreveu vários artigos, reunidos em seu livro Os Assassinos da Memória (Campinas: Papirus, 1988). Em alguns deles, conseguiu construir sínteses esclarecedoras sobre o impacto das interpretações negacionistas.

Pode-se, para concluir, tentar descrever as provações às quais o revisionismo submete o historiador? Ao refletir, depois da guerra, sobre o tema da "dialética negativa", Adorno perguntava-se em que medida era "possível" pensar após Auschwitz. O que o terremoto de Lisboa foi para Voltaire, o túmulo de teodicidade para Leibniz, o genocídio é centuplicado, para a geração que o viveu: "Com o massacre pela administração de milhões de pessoas, a morte tornou-se algo que nunca se teve de temer sob essa forma (...). O genocídio é a integração absoluta que se prepara em toda parte onde os homens são nivelados, adestrados, como se diz no exército, até que, presos ao conceito de sua inanidade total, são literalmente exterminados (...). A negatividade absoluta é previsível, já não surpreende ninguém." Negatividade absoluta? Esse conceito teria algum sentido para o historiador? Auschwitz reunia um campo de extermínio (Birkenau), um campo de trabalho (Auschwitz I) e um campo-fábrica de borracha sintética (Auschwitz III Monowitz). O local da negatividade absoluta seria mais Treblinka ou Belzec, mas é sempre possível conceber um crime mais absoluto que um outro. Por definição, o historiador vive no relativo, e é justamente isso que torna a apreensão do discurso revisionista tão difícil para ele. 0 próprio termo nada tem para chocar o historiador: por instinto, toma posse desse adjetivo. Se lhe for demonstrado que não havia qualquer câmara de gás em funcionamento em Dachau, que o diário de Anne Frank tal como foi editado em várias línguas coloca problemas de coerência e até de autenticidade, ou que o Krema I, do campo de Auschwitz propriamente dito foi reconstruído após a guerra pelos Poloneses, está pronto a curvar-se.

Os acontecimentos não são coisas, mesmo que exista uma opacidade irredutível do real. Um discurso histórico é uma rede de explicações que pode ceder espaço a uma outra explicação que será considerada como melhor reveladora do diverso. Por exemplo, um marxista tentará raciocinar em termos de rentabilidade capitalista e irá perguntar-se se a destruição pura nas câmaras de gás se inscreve ou não facilmente nesse sistema interpretativo. De acordo com o caso, adaptará as câmaras de gás ao marxismo ou irá suprimi-las em nome da mesma doutrina. No entanto, em sua essência, o empreendimento revisionista não parece tentar obter "outra explicação" dessa pesquisa. É melhor nele procurar a negatividade absoluta de que fala Adorno, e é precisamente isso que é tão difícil de o historiador compreender. Trata-se de um esforço gigantesco não só para criar um mundo de ficção, mas para apagar um imenso acontecimento da história.

Nessa ordem de ideias, devemos admitir que dois livros revisionistas, The Hoax of the 20th

6 Aspectos importantes desse processo foram recriados ficcionalmente no filme Negação (2016, direção: Mick Jackson, roteiro: David Hare). 
Century de Arthur Butz e Der Auschwitz Mythos de Wilhelm Stäglich representam um êxito bastante notável: o da aparência de um relato histórico, ou melhor de uma pesquisa crítica com todas as características externas que definem o livro de História, excetuando-se aquilo que de fato faz o seu mérito: a verdade.

Naturalmente podemos procurar e encontrar precedentes do revisionismo na história dos movimentos ideológicos. Sob a Restauração, o RP Loriquet não havia apagado com objetivos educacionais a Revolução e o Império da história que ensinava aos seus jovens alunos? Mas só se tratava de fraude "legítima", que, desde Platão, sabemos inseparável da Educação - um jogo inocente em relação aos revisionismos modernos.

Naturalmente se posso falar aqui do absoluto é porque nos encontramos no plano do discurso puro, não do real. O revisionismo é coisa antiga, mas só aconteceu no Ocidente após a difusão maciça de Holocausto, ou seja, após a espetacularização do genocídio, sua transformação em linguagem pura e objeto de consumo das massas. Parece que acabei de colocar aqui o ponto de partida para uma reflexão que, espero, outros, além de mim, continuarão (VIDAL-NAQUET, 1988, p. 147-151).

Essa longa passagem fornece elementos muito importantes para vislumbrar as permanências e as rupturas ao longo dos processos históricos. O argumento apresentado por Vidal-Naquet, de imediato, nos remete à ideia de que, após os acontecimentos de Auschwitz, determinados horrores estariam superados, pelo menos, para a História do Ocidente. Porém, como foi largamente demonstrado, e não percebemos ou não quisemos perceber, o horror e o inominável mudaram de rostos, de etnias, de nomes e os séculos XX e XXI continuaram a produzir escombros e eles estão se avolumando perante nossos olhos.

Nesse processo, imaginávamos essas temáticas superadas, no sentido de o conjunto de evidências e de interpretações já terem consolidado um processo de memorização, mas ele foi abruptamente confrontado. Como? Não bastavam as tragédias advindas dos campos de concentração? A veracidade das narrativas dos sobreviventes precisava ser colocada em suspensão?

O tema do Holocausto chegara até nós por diversos caminhos: depoimentos, literatura de testemunho, filmes, documentários, museus, memoriais, visitas a campos de concentração, que foram identificados, por Vidal-Naquet, como instituintes de uma prática de espetacularização. Nesse sentido, ainda tendo por base as suas palavras, provavelmente, a monumentalização em excesso gerou a dúvida por parte dos insatisfeitos com tais procedimentos.

Nesse embate, acadêmicos e livres-pensadores negacionistas, cada qual a seu modo, sentiram-se impelidos a revisitarem documentos e, a partir deles, elaborarem interpretações. Os recursos utilizados, além da distorção de informações, pautaram-se, por um lado, pela premissa de não se poder provar a existência dos campos de concentração, pois não havia referências explícitas a eles e às câmaras de gás, no material consultado, bem como, colocaram sob suspeição os depoimentos de sobreviventes, qualificados, por inúmeros estudiosos, como evidências irrefutáveis.

Aproveitaram-se das possibilidades interpretativas, intrínsecas à pesquisa histórica, e as confrontaram no que lhes era mais sensível do ponto de vista moral em relação à própria humanidade.

Porém, algo ficou em suspenso: como se justificam as significativas repercussões recebidas pelas teses negacionistas do Holocausto? Como desdobramento dessa indagação, será necessário reconhecer no tecido social bases para recepção dessas teses? Se essas perguntas são factíveis, é correto inferir: o antissemitismo, disseminado, ao longo dos séculos, não foi suplantado por ações que visavam repudiar o nazismo e os campos de concentração? 
|l|

Nesse momento, para dar continuidade a esse debate, novamente, retorno à minhas origens: pensar o processo histórico pelos princípios de realidade contidos nos objetos artísticos, em especial, nos textos teatrais. Para tanto, reporto-me à peça de Thomas Bernhard, Praça dos Heróis escrita em 1988, para comemoração do centenário do Burgtheater de Viena, por encomenda de Claus Peymann, na época, responsável pela direção do teatro.

Em 13 de março de 1938, sob aplausos frenéticos, Adolf Hitler anunciava aos vienenses reunidos na Praça dos Heróis [Heldenplatz] a anexação da Áustria à Alemanha. Cinquenta anos mais tarde, em um apartamento próximo à praça, a família Schuster reúne os amigos mais próximos. A ocasião: o enterro do professor catedrático Josef Schuster. Esse intelectual, que havia sido expulso pelos nazistas e que, a pedido do prefeito de Viena, voltara de Oxford para reassumir a cadeira de professor, não via outra saída senão o suicídio. Pois a situação da Áustria naquele momento era "pior do que há cinquenta anos".

Na peça mais política de Bernhard, o destino de Josef Schuster ilustra bem as condições da Áustria em termos de política, de moral e de espiritualidade. [...]. Antes mesmo de sua estreia, a peça provocou um enorme escândalo na Áustria. Uma onda de indignação transformou o país num cenário ideal para este drama. Assim, por exemplo, o então presidente da República, Kurt Waldheim, disse: "Considero essa peça uma ofensa grosseira ao povo austríaco...". E Bernhard responde: "Sim, minha peça é horrível, mas o teatro que se passa em torno dela é igualmente horrível" (FLORY In: BERNHARD, 2020, p. 9).

A leitura desse fragmento, parte integrante da Nota da edição alemã expõe, de forma contundente, o confronto de Thomas Bernhard com a sociedade vienense. Mas por quê?

\begin{abstract}
Uma peça para ser montada por ocasião das comemorações do centenário da inauguração daquele teatro - as quais coincidiam com eventos relacionados à memória dos cinquenta anos da anexação, no final da década de 1930. Havia, à época, um grande esforço para que os eventos relativos a 1938 reafirmassem e consolidassem a leitura de que a Áustria fora a primeira vítima do nazismo, numa anexação forçada. Os eventos procuravam, em especial, esquecer o escândalo da eleição à presidência de Kurt Waldheim dois anos antes, em 1986. Waldheim fora eleito apesar de, ao longo da campanha, ficar provado que ele participara das tropas SS no período do nazismo. Esse episódio, entre outros, fez com que a década de 1980 se constituísse como um momento de enfrentamento e de discussão sobre o passado nazista austríaco, até mesmo sobre como qualificar a anexação: ela teria sido forçada ou, ao contrário, uma adesão voluntária? Os eventos oficiais que rememoravam o episódio procuravam, na contramão dessa perspectiva crítica, reforçar o processo de vitimização do país (FLORY In: BERNHARD, 2020, p. 12).
\end{abstract}

As informações oferecidas por Alexandre Villibor Flory revelam os princípios de realidade motivadores da escrita de Praça dos Heróis: apropriar-se das efemérides, a fim de demonstrar como, ao invés de rupturas, do ponto de vista político-cultural, a perspectiva antissemita continuava a orientar práticas e escolhas sociais, institucionais.

Para tanto, Thomas Bernhard construiu uma estrutura dramática dividida em três grandes

7 No Brasil, Praça dos Heróis foi encenada no Theatro São Pedro, Porto Alegre, em 21 de julho de 2005, sob a direção de Luciano Alabarse. 
cenas. A primeira, ambientada no apartamento do Professor Schuster, é protagonizada pelas funcionárias da casa: Sra. Zittel e Herta. Na segunda, o leitor/espectador acompanha a conversa mantida, durante o trajeto após o enterro do Professor, entre seu irmão, Prof. Robert, Anna e Olga, filhas do casal Schuster. Já na derradeira cena, na sala de jantar do apartamento situado à Praça dos Heróis, estão sentados à mesa: Sra Schuster, Prof. Robert, Olga, Anna, o casal Liebig, Sr. Landauer e Lukas. Todos são servidos pela Sra. Zittel e por Herta.

Quais os motivos do encontro dessas personagens?

O Professor Schuster suicidou-se e as funcionárias estão embalando os pertences da família. Devido ao trágico ocorrido? Não. Nos dias anteriores a tal desfecho, a família Schuster estava de mudança para Inglaterra. O Professor iria retomar suas aulas em Oxford, universidade na qual trabalhara havia vinte e cinco anos atrás.

Quando Hitler anexou a Áustria, os Schuster se retiraram do país e o Professor foi exercer seu ofício no Reino Unido. Com o fim da Segunda Guerra e a consequente derrota do exército nazista, aos poucos, a ordem anterior começou a ser restabelecida e o Professor Schuster aceitou o convite do prefeito de Viena para retornar à sua terra natal e retomar suas atividades na Universidade de Viena.

A família regressou a Áustria e ao apartamento situado à Praça dos Heróis, local onde a população vienense se reuniu para euforicamente acompanhar a entrada triunfal de Adolf Hitler. Embora tudo estivesse em aparente harmonia, a Sra. Schuster preferia a residência situada em Neuhaus, pois, de maneira recorrente, a sua memória ativava os ruídos daquela noite, que permaneceram na história do país.

Sim, a Sra. Schuster tinha dificuldades em conviver com esse passado. No entanto, foi seu marido quem se suicidou e as pistas acerca das possíveis razões do gesto tão definitivo foram, aos poucos, apresentadas.

As funcionárias, enquanto realizavam suas tarefas, conversavam sobre suas obrigações particulares, sobre os gostos e os interesses do patrão, enfim, por seus diálogos, somos introduzidos, com parcimônia, no universo daquela família burguesa, com perfil aristocrático. As personagens nos são apresentadas pelos seus perfis sociais, seus valores e interesses. Não há, em absoluto, dimensões psicológicas e/ou características individuais. Porém, as informações, displicentemente reveladas, demonstram a existência de um sintoma social, que impede a eles, privilegiados, desfrutarem os benefícios de seus nascimentos. Acerca da Sra. Schuster, nos é revelado:

\section{SRA ZITTEL - Eu não posso deixar o apartamento} só porque você ouve essa gritaria da Praça dos Heróis ele sempre repetia significaria que pela segunda vez esse Hitler me expulsou do meu apartamento ele pensou que adiantaria se ela tapasse os ouvidos mas é claro que não adiantou nada também à noite ela ouve a gritaria da Praça dos Heróis

(BERNHARD, 2020, p. 48) 
Começa, assim, a ser delineado o temor que assombra a família Schuster. Um passado/presente atualizado, de maneira constante, nos medos e nas angústias de quem não consegue esquecer. Contudo, a aparente imagem da sobrevivência do sentimento de terror, apenas nas entranhas do cérebro da Sra. Schuster, é mais à frente desfeita quando a governanta recorda as palavras do Professor:

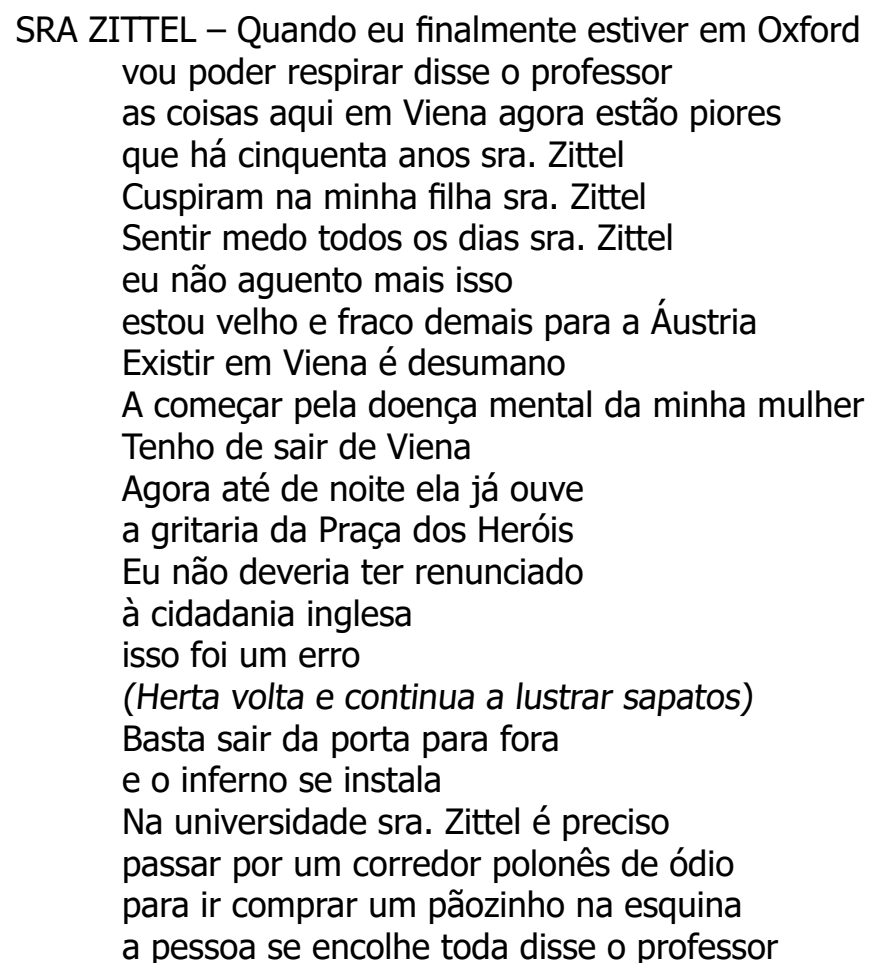

(BERNHARD, 2020, p. 62)

Por esse diálogo, o leitor/espectador tem acesso a evidências. Elas apontam para a presença de práticas discriminatórias na sociedade vienense, demonstrando um lastro de continuidade entre 1938 e 1988. De fato, os nazistas foram derrotados, mas o antissemitismo continuou a fazer parte da cultura austríaca e se intensificou no decorrer do século XIX, como bem demonstrou o historiador Carl E. Schorske, ao pensar o ambiente de Viena, a partir da definição de geração utilizada por Wilhelm Dilthey ${ }^{8}$.

8 "Dilthey levantou a questão teórica do papel das gerações na mudança cultural. Ele estava então estudando uma crise anterior profunda da burguesia alemã, a da Revolução Francesa, que deu origem ao romantismo alemão. Dilthey descobriu que muitos dos românticos mais criativos - Schlegel, Schleiermacher, Hegel, Hördelin, Novalis, Tieck - haviam nascido numa mesma década. Consciente de que estava tratando de um grupo pequeno, Dilthey evitou uma definição de geração aplicável a toda a sociedade: '[Uma] geração é constituída por um círculo restrito de indivíduos que estão ligados a um todo homogêneo por sua dependência dos mesmos grandes eventos e transformações que aparecem em sua época de [máxima] receptividade, apesar da variedade de outros fatores subsequentes"' (SCHORSKE, 2000, p. 177) 
No caso de Viena, os pioneiros da alta cultura do século XX se ajustam à definição de Dilthey. O centro geracional de gravidade de nossos criadores de cultura cai no começo da década de 1860; seu contexto formador, o fracasso do liberalismo austríaco na era da unificação e depressão germânica, na década de 1870 . O fato de a universidade se tornar o centro da frustração política para os herdeiros das famílias liberais dotou a rebelião dos Jungen de uma nitidez inicial de definição de grupo etário e introduziu a tensão edipiana no antagonismo político. Mais significativo para o futuro do liberalismo como sistema de valores foi que Die Jungen desenvolveram a contracultura dionisíaca e populista como suporte para suas críticas e aspirações políticas. Essa contracultura entregou-se ao antissemitismo, da mesma forma que o racionalismo jacobino gerou o reino do terror, com suas graves consequências intelectuais para a cultura iluminista. Por outro lado, para aqueles que recuaram chocados diante das consequências racistas de seu nacionalismo, a cultura dionisíaca e a dissolução do ego racionalista que a acompanhava tornaram possível a exploração da psique, a recuperação da dimensão não racional do homem em toda a sua riqueza e ambiguidade (SCHORSKE, 2000, p. 177-178).

Essa passagem luminosa fornece uma chave importante para compreender as bases históricas e culturais da emergência do antissemitismo. Provavelmente, a partir desse ambiente, Thomas Bernhard teceu os fios de sustentação ao argumento da permanência da discriminação em solo austríaco.

Para isso, construiu as suas personagens no ambiente da elite intelectual e econômica de Viena. Como desdobramento dessa caracterização, elas não possuem empatia alguma para com os segmentos sociais menos privilegiados, assim como nutrem desprezo significativo pela cultura de massas e pelo processo de modernização do século XX.

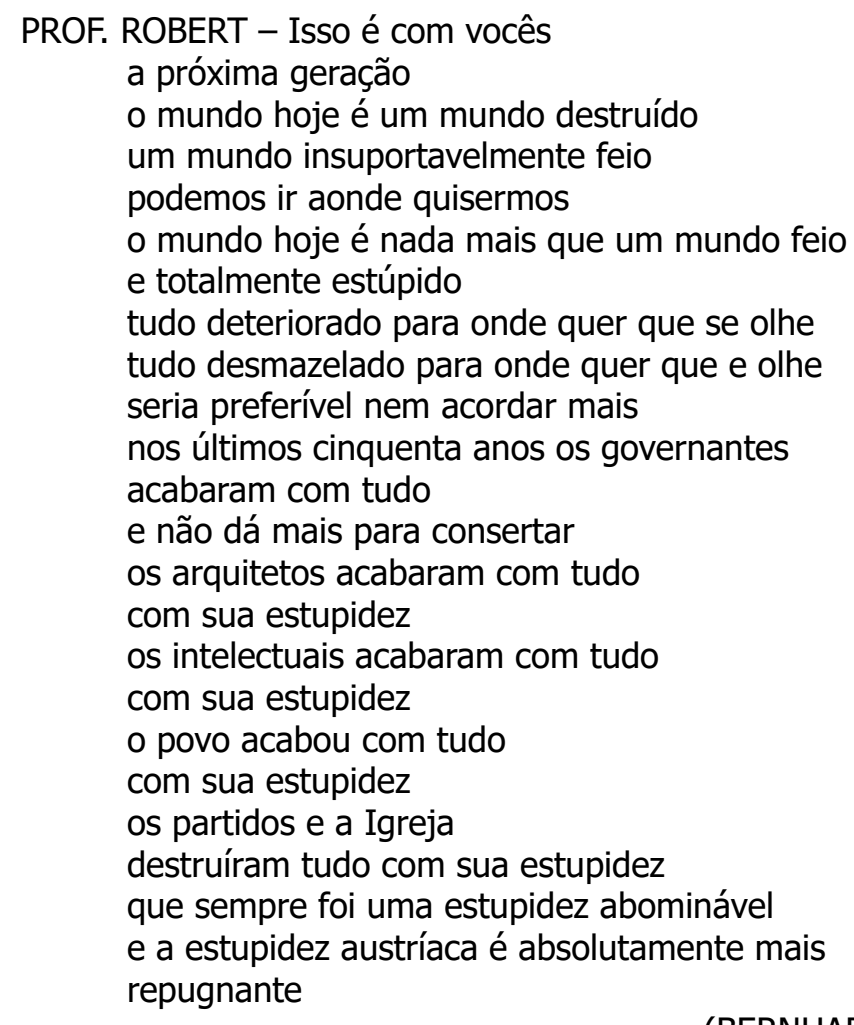

(BERNHARD: 2020, 103) 
Esse processo de modernização produziu conhecimento, avanços tecnológicos e em alguns países o denominado estado do bem-estar social. Mas, valores solidários, com justiça social e com o respeito à diferença, como bem observou a personagem Cardeal Lamberto, ficaram na superfície. Não permearam as sociedades. Ao contrário, sob o aparente processo civilizatório, violências e discriminações se mantiveram.

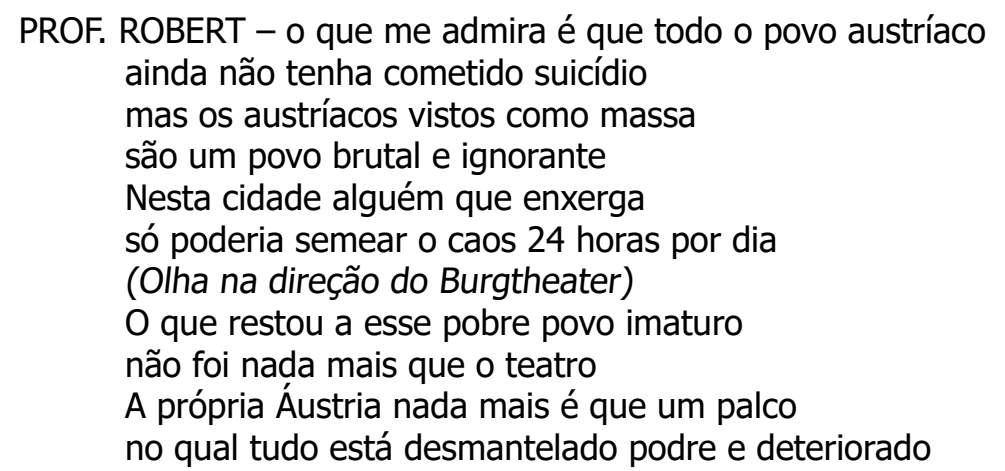

(BERNHARD: 2020, 104)

Mais à frente, em continuidade ao desabafo de descrença frente às sociedades contemporâneas, a personagem afirma:

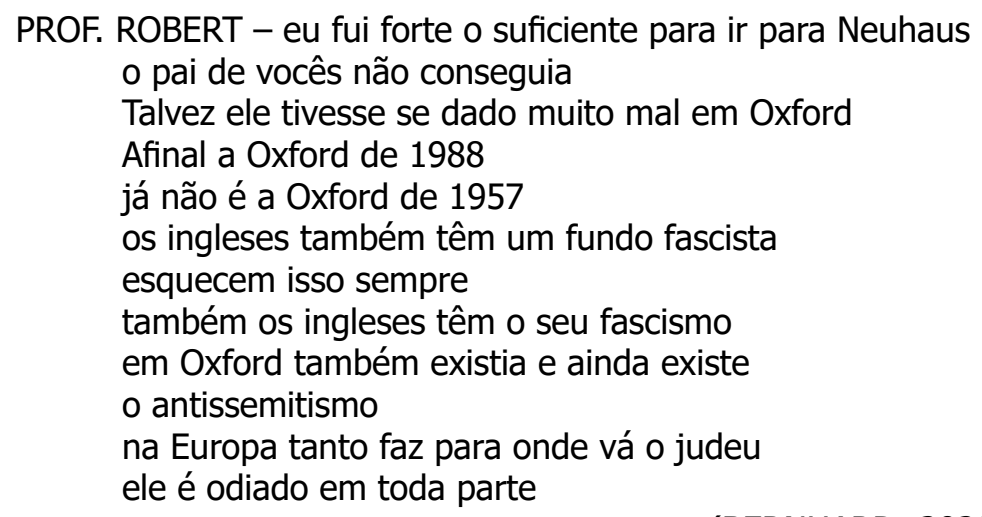

(BERNHARD: 2020, 105-106)

Por fim, como a coroar os esforços para demonstrar seu argumento, as personagens Anna e Prof. Robert travam o seguinte diálogo:

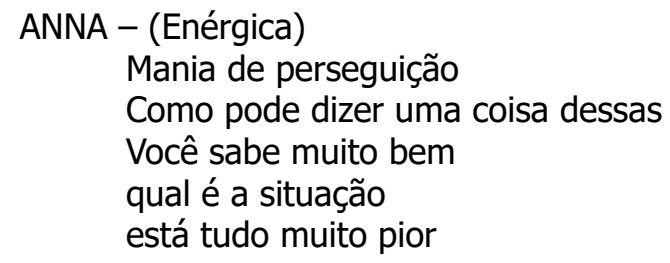




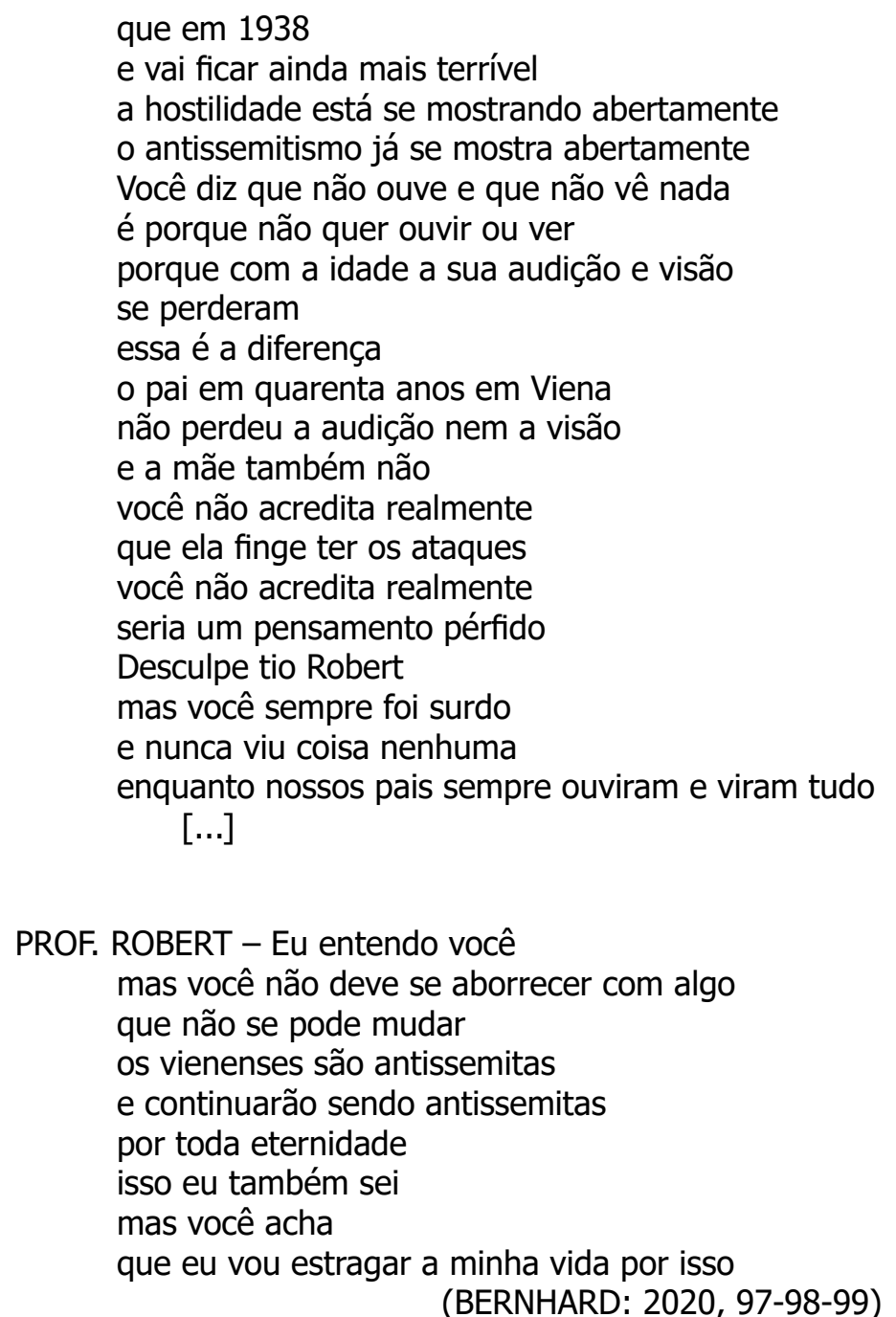

(BERNHARD: 2020, 97-98-99)

Os trechos recortados, dentre tantos outros possíveis, expõem a temática central de Praça dos Heróis. Ela não está organizada em conflitos individuais ou familiares, mas em uma perspectiva histórica. Por conseguinte, a sua narrativa se estrutura pelo épico, alternando diálogos específicos, como demonstrados acima, com longas exposições, que ora versaram sobre situações particulares, ora narraram vivências de outros.

Sob esse prisma, acontecimentos foram atualizados e, graças a essa estratégia, somos merguIhados em conflitos, que perpassam o tecido social e cultural, no sentido de evidenciar: o preconceito e a discriminação não se dissipam por atos administrativos, mas, fundamentalmente, por práticas democráticas, pois, por um lado, devem disseminar a noção de cidadania e, de outro, precisam tensionar os conflitos, com o intuito de expô-los para o debate social, político e cultural.

É evidente: uma análise mais detalhada da peça de Thomas Bernhard traria desdobramentos ainda mais contundentes acerca do papel da burguesia, do olhar hierarquizado sobre a estrutura social, além de exacerbação de valores e inúmeros preconceitos.

Contudo, para não perder o leitmotiv orientador deste artigo, optei por evidenciar como um processo de discriminação permaneceu ao longo dos séculos e como, em diferentes circunstâncias, ele reaparece e se externa como continuidade. Dessa feita, as rupturas, vistas como tão definitivas, 
são, na verdade, frágeis superfícies de caudalosas formações, que se apresentam e se renovam no decorrer dos tempos.

IV

Enfim, foi a sensação de estranheza, incômodo e insatisfação de nosso tempo presente que me motivaram na escrita desse texto. Tempos esquisitos!

Como fiz questão de ressaltar, na primeira parte, estamos vivendo em meio a mazelas de toda sorte: misérias, injustiças, exacerbação do poder do capital financeiro, acrescidos da crise ambiental, energética e por aí afora. Entretanto, somente quando posturas conservadoras, e várias delas negacionistas de todos esses acontecimentos, chegaram ao poder executivo, as sociedades civis começaram a se manifestar.

Mas, não deixa de ser curioso: essas concepções políticas já estavam presentes em várias casas legislativas e nós simplesmente não nos atentamos para isso, assim como inúmeros intelectuais e setores formadores de opinião consideraram como parte do jogo democrático permitir a divulgação de falácias, como os argumentos contra a existência dos campos de extermínio, e assistir passivamente à exaltação de torturadores alçados à condição de heróis da pátria.

Deixamos de ler atentamente a Constituição e, em vista disso, presenciamos desobediências civis em diversas regiões do planeta. Como chegamos a isso?

Para mim, uma resposta válida e possível nos foi dada pelo filósofo Herbert Marcuse e, para muitos, uma hipótese pouco considerada:

o ataque conjugado contra a educação que não seja "profissional" e "científica" já não se limita à repressão normal através das verbas. Assim, o Reitor das Universidades Estaduais da Califórnia quer restrições sistemáticas aos estudos humanistas e às Ciências Sociais, onde a educação tradicionalmente não-conformista encontrou um nicho. "Muitos estudantes estão chegando à universidade sem saber ao certo por que aí se encontram...Optaram quase como um reflexo pelas humanidades e Ciências Sociais, sem quaisquer objetivos ocupacionais específicos (Los Angeles Times, 17 de novembro de 1971)". Houve um tempo em que o princípio proclamado da grande filosofia burguesa foi que a juventude "devia ser educada não para o presente, mas para uma melhor condição futura da raça humana, isto é, para a ideia de humanidade". Agora, o Conselho para a Educação Superior é convocado para estudar as "necessidades detalhadas" da sociedade estabelecida, a fim de que as universidades saibam "que espécie de diplomados thes cabe produzir" (MARCUSE: 1973, 35-36).

Salvo avaliações mais qualificadas, como sociedade, renunciamos à formação para a cidadania e os impactos, acredito, estamos vivenciando nesse momento histórico. São importantes a eficiência, os lucros e a vontade dessa entidade abstrata chamada mercado, que, na verdade, agrega nomes, interesses e estratégias de ação política e econômica. Enquanto, inúmeros segmentos sociais, meios de comunicação, autoridades do setor legislativo e jurídico se limitam a dizer: as instituições estão funcionando.

Na semana do término desse texto, o Colégio Eleitoral norte-americano confirmou a vitória do democrata Joe Biden à Presidência da República, com 306 votos contra 232 votos de seu adversário, o atual presidente Donald Trump. Na consulta popular foram 81,3 milhões de votos para Biden, 
$51,3 \%$ do total de cédulas apuradas, contra 74,2 milhões para Trump, perfazendo a porcentagem de $46,8 \%$.

A vitória do candidato do Partido Democrata foi festejada na maioria dos países. Todavia, deixamos de considerar: quase $50 \%$ dos norte-americanos escolheram Donald Trump, um dos mais importantes negacionistas da atualidade. Isso significa algo?

Para mim, as instituições continuam em perigo porque as práticas anticonstitucionais, sectárias e autoritárias do presidente derrotado encontram eco entre inúmeros cidadãos de bem.

Por ter tal percepção dessa história imediata, escolhi a peça Praça dos Heróis. O texto soa como um alerta: temos de permanecer vigilantes, críticos e não aceitarmos simplesmente a ideia de que tudo, ao nosso redor, é natural.

Nesse momento, interpretações definitivas para um processo em aberto são sempre muito temerárias, mas, quando me reporto aos debates contemporâneos sobre como preservar espaços democráticos, considero cada vez mais oportuno irmos além das denominadas garantias institucionais, imprescindíveis, porém não suficientes para o exercício da democracia.

A construção de uma cultura democrática é, a meu ver, o grande desafio da contemporaneidade, pois a sua abrangência só se tornará visível a partir de demandas nas quais diferenças sejam mantidas e desigualdades, por sua vez, derrotadas.

\begin{abstract}
A sociedade atual parece-me com uma máquina imensa que está tragando continuamente os homens, e cujos comandos ninguém conhece; e os que se sacrificam pelo progresso social se parecem com pessoas que se agarram aos rolamentos e às correias de transmissão para tentar deter as máquinas fazendo-se moer por sua vez. Mas a impotência em que nos encontramos em dado momento, impotência que nunca deve ser encarada como definitiva, não pode dispensar que se permaneça fiel a si mesmo, nem desculpar a capitulação ante o inimigo, seja qual for a máscara que use. $\mathrm{E}$, debaixo de todos os nomes sob os quais ele se pode disfarçar, fascismo, democracia ou ditadura do proletariado, o inimigo básico é o aparelho administrativo, policial e militar; não o da frente, que é nosso inimigo tanto quanto de nossos irmãos, mas o que se diz nosso defensor, que nos transforma em seus escravos. Em qualquer circunstância, a pior traição possível é sempre aceitar a subordinação a esse aparelho e pisar, para servi-lo, em si mesmo e nos outros, todos os valores humanos (WEIL,1979, p. 180).
\end{abstract}

Simone Weil, para mim, sempre foi grande inspiração, especialmente pelo fato de, em seus escritos, suscitar a desestabilização do já instituído e nos convidar a desafios políticos e epistemológicos. Assim, de forma mais modesta, espero que esse artigo possa contribuir com nossas reflexões e desafios do tempo presente!

Referências

BERNHARD, Thomas. Praça dos Heróis. São Paulo: Temporal, 2020.

FURET, François. O passado de uma ilusão. São Paulo: Siciliano, 1995.

MARCUSE, Herbert. Contrarrevolução e Revolta. Rio de Janeiro: Zahar Editores, 1973. 
SCHORSKE, Carl E. Tensão geracional e mudança cultural. In: SCHORSKE, Carl E. Pensando com a História: indagações na passagem para o modernismo. São Paulo: Companhia das Letras, 2000.

SCHORSKE, Carl E. Viena fin-de-siècle: política e cultura. São Paulo: Companhia das Letras, 1988.

SIGNEU, Samir (org.). Thomas Bernhard, o fazedor de teatro e a sua dramaturgia do discurso e da provocação. São Paulo: Perspectiva, 2017.

VIDAL-NAQUET. A História após Auschwitz. In: VIDAL-NAQUET. Os assassinos da memória: Um Eichmann de papel e outros ensaios sobre o revisionismo. Campinas: Papirus, 1988.

WEIL, Simone. Reflexões sobre a Guerra. In: BOSI, Ecléa (org.). A condição operária e outros estudos sobre a opressão. Rio de Janeiro: Paz e Terra, 1979. 